\title{
Colloquy
}

\section{BE KIND: Negotiating Ethical Proximities in Aotearoa/New Zealand during COVID-19}

\author{
SUSANNA TRNKA \\ University of Auckland \\ (D) http:/ / orcid.org/0000-0002-4779-8035
}

When Aotearoa/New Zealand's prime minister Jacinda Ardern declared the nation's first COVID-19 lockdown in March 2020, she urged the public: "Be kind. I know people will want to act as enforcers. And I understand that, people are afraid and anxious. We will play that role for you. What we need from you, is to support one another. . . We will get through this together, but only if we stick together. Be strong and be kind” (Ardern 2020).

During the forty-nine-day lockdown, members of the public did indeed "act as enforcers." So much so that police phone lines crashed from a flood of reports of people deemed "too close" to one another, straying "too far" from their "own" neighborhoods, or unnecessarily occupying public areas. A new online form for reporting breaches received 9,600 submissions in forty-eight hours (in a country whose total population numbers five million).

Scholarly examinations of states of emergency highlight how the crisis imaginary (cf. Koselleck 2006; Roitman 2013) is employed to unjustifiably expand state power (Foucault 2004; Agamben 2005, 2020; Chomsky 2020), often portraying the citizenry as weak or duped by state propaganda. Such representations risk eclipsing how citizens may not only desire states of emergency (Fassin 2012; Ap- 
padurai 2020) but also act as their supporters, lawbreakers, critics, arbiters, and enforcers. Members of democratic societies actively promote or destabilize states of emergency, in the words of the political theorist Bonnie Honig (2009, 111), "resisting the irresistible, demanding accountability from those who present themselves as beyond such demands, taking exception to the exception, enacting collective life otherwise." Such contestation, moreover, occurs in situations of distrust between citizens and the state, as Carolyn M. Rouse (2021, this issue) elucidates in her Colloquy contribution, as well as more amicable ones. Given that lockdown requires adopting novel kinds of spatial relations, many of the activities over which New Zealanders reasoned and debated, subverted and supported, punished and surveilled concentrated on ethical proximities, not only in terms of maintaining distance but also keeping near that or those one deemed should be close. ${ }^{1}$

The maintenance of "proper distance" is an ethical act and an ordinary facet of social life (Silverstone 2003). Proximity's (ethical) significance was thrown into relief during lockdown through the effort required to uphold new legal regulations. Following the government's mandate that physical interaction be largely restricted to those who shared residences or household "bubbles," for many, the ongoing question became not whether to comply, but how, when, and to what extent possible. Abilities to make choices were shaped by long-standing axes of disadvantage, notably class and ethnicity (as explored in other settings by Levine and Manderson 2021, this issue; Rouse 2021, this issue; Wynn 2021, this issue), alongside new variables such as occupation (e.g., essential service work) and household and family composition (Trnka et al. 2021). Given the stresses of physical distancing and the existential burdens of coping with a pandemic, ethical decision-making focused not only on how to maintain boundaries but how to keep proximate those "near to us" suddenly made distant.

\section{"BE STRONG AND BE KIND"}

From March 26 to May 13, 2020, the New Zealand public was ordered to "stay home" unless exercising, seeking essential supplies or medical care, or providing essential services. Like many ethnographers of lockdown, I adopted various research strategies while predominantly house bound, including analyzing government messaging and media coverage, transforming opportunities for exercise into "walking ethnographies" (Pink et al. 2010), and joining an interdisciplinary research team that conducted an online survey of New Zealanders' experiences.

Immediately noticeable was the sudden flurry of government posters, flyers, and ads promoting the pandemic response as a collective project, emblazoned 
with messages of positivity and national unity: "be kind"; "we got this!"; "we're all in this together"; "unite against COVID-19." Media organizations and commercial enterprises followed suit, capitalizing on the twin mantras of kindness and unity. The nation's largest insurance company, for example, launched a "Kindness is Everything" ad campaign, urging viewers to "keep some of this kindness we've learned of late" (AMI Insurance 2020). Broad segments of the public engaged in similar assertions of collective care, propping teddy bears in windows or visibly commemorating ANZAC Day (the equivalent of Memorial Day in the United States) with red poppies (Trnka 2020). Combatting COVID-19 was portrayed as a unified, national effort, forward looking while historically resonant.

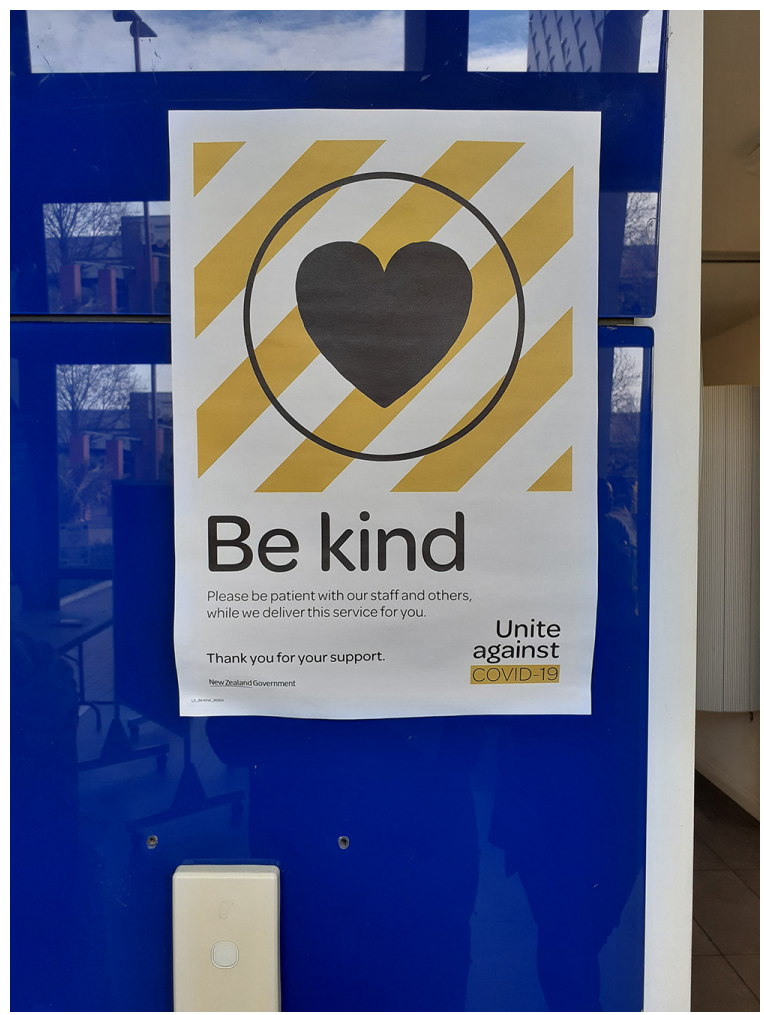

Figure 1. Government poster, found across the country in early and mid-2020. Photo by Susanna Trnka.

Not everyone, however, acceded to lockdown prohibitions. As Thomas Strong (2021, this issue) reminds us, the government's abilities to curtail activity are never all-encompassing. Even among those committed to "eradicating" the virus, dedication sometimes yielded to other obligations, needs, or desires. 


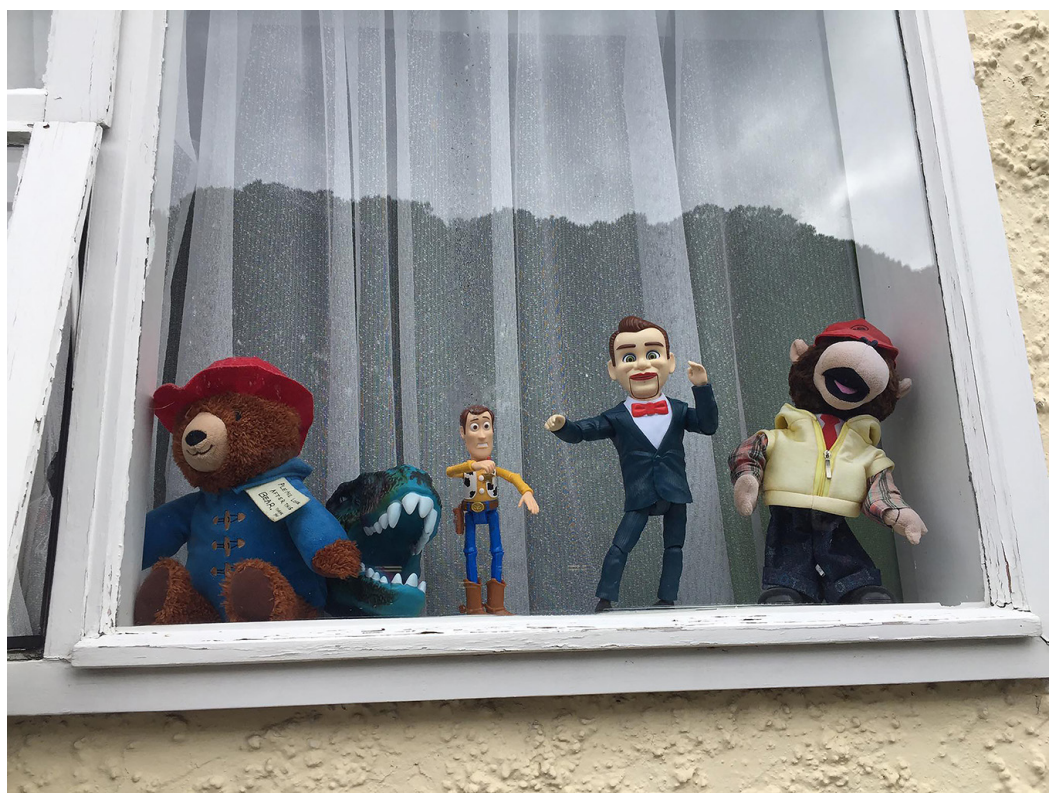

Figure 2. Around the nation, teddy bears, stuffed animals, and figurines appeared in windows to indicate support and solidarity for the national lockdown. Photo by Revena Correll Trnka.

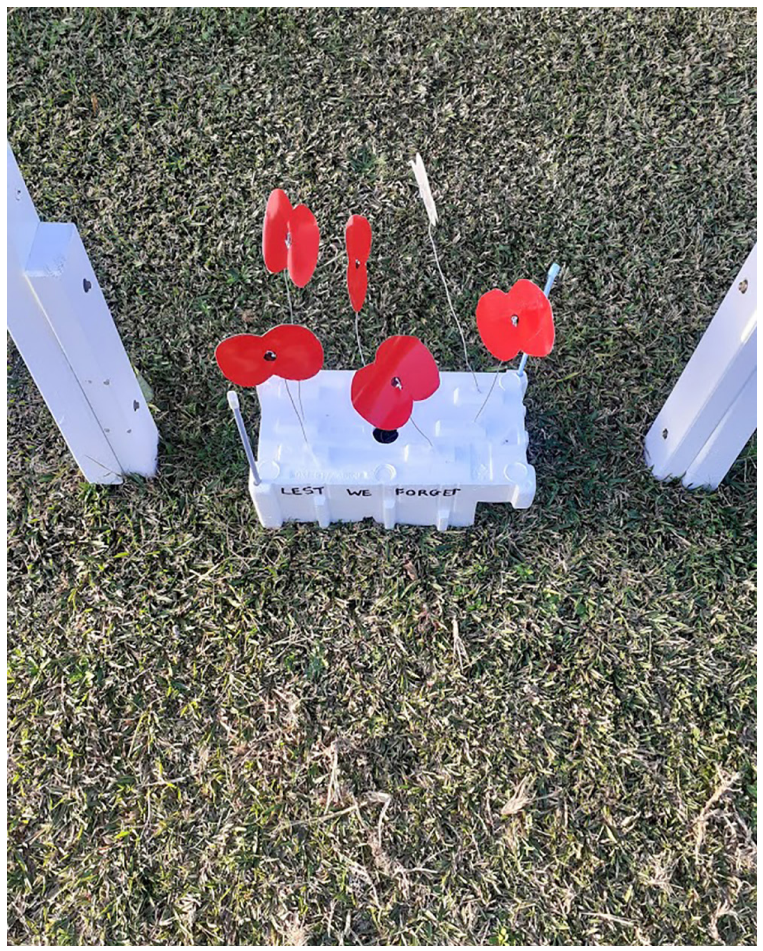

Figure 3. Display of poppies during ANZAC Day. Photo by Susanna Trnka. 
Most of the 3,644 New Zealanders who answered our online survey strongly supported lockdown regulations. Many of the same people, however, recounted knowingly contravening them (Long et al. 2020; Trnka et al. 2021). Often this resulted from "competing responsibilities" (Trnka and Trundle 2017), pulling them in multiple directions. Committed to "the team of five million," they endeavored to uphold lockdown measures, but found that the ethical demands of close-relations-made-distant proved too powerful, physically meeting with friends and loved ones from whom they'd been mandated to stay apart, particularly those who were struggling.

Several recounted circumstances where they felt the need to break the law was obvious and required little explanation, noting, for example (in reference to a friend), "they were living alone and were sad." Others had undergone intensive moral debates: should a dying man be driven to the hospital by his daughter or should a friend (outside their bubble) drive them together, enabling the daughter to focus on her father's final needs? Some practiced physical distancing while nonetheless contravening regulations, for example, sharing a beer at opposite ends of the driveway following a family member's death. Breaches frequently involved connecting with others via physical touch or co-presence, enabling communication and communion unachievable through technology.

Simultaneously, discomfort arose between those thrust together in ways deemed too close, including cohabitants without bonds of kinship or friendship such as cotenants or lodgers. Appropriate spatial/affective/ethical distances collapsed when someone fell sick or felt mentally vulnerable while confined to a household of strangers. Intimacies were forced when only one person within a residential bubble of otherwise unconnected individuals was allowed to purchase groceries (Trnka and Davies 2021). These instances revealed how the practical and existential demands of care did not fit the relationalities with which they were involuntarily aligned.

While misaligned care-relations created a significant source of strain (cf. Long 2020), other motivations existed for breaking the law, including pleasure-seeking and - seemingly ironically - the enforcement of emergency measures.

At the height of lockdown, outdoor activities that might require rescue assistance (e.g., surfing, boating) were banned. Alongside police warnings and possible arrest, rule-breakers faced public condemnation. A highly publicized case involved a surfer ordered out of the water at Piha Beach who was photographed approaching police with his middle finger extended. A news site captioned the image, "A surfer is not happy to be questioned by police . . .," and quoted a local academic 
declaring that surfers were "taking advantage of every other New Zealander who is staying at home" and "the more people who flout the rules, the longer we'll be in lockdown" (Owen 2020). Over the following forty-eight hours, the surfer received multiple death threats.

The backlash against the surfer proved particularly dramatic perhaps because his breach reverberated across multiple registers of the law (cf. Das 2004). Indisputably, he disobeyed lockdown regulations. It was implied he threatened the police. Public outrage was also fanned by the image of a man (surfer) gesturing threateningly toward a woman (officer). Just as importantly, the surfer contravened the government's unity campaign: he broke not just the rules but the spirit of the lockdown. The ethical implications of his actions were publicly calibrated not against potential contagion (few believe surfing spreads COVID-19) but against the perceived dangers of someone "in our midst" shattering images of national cohesion.

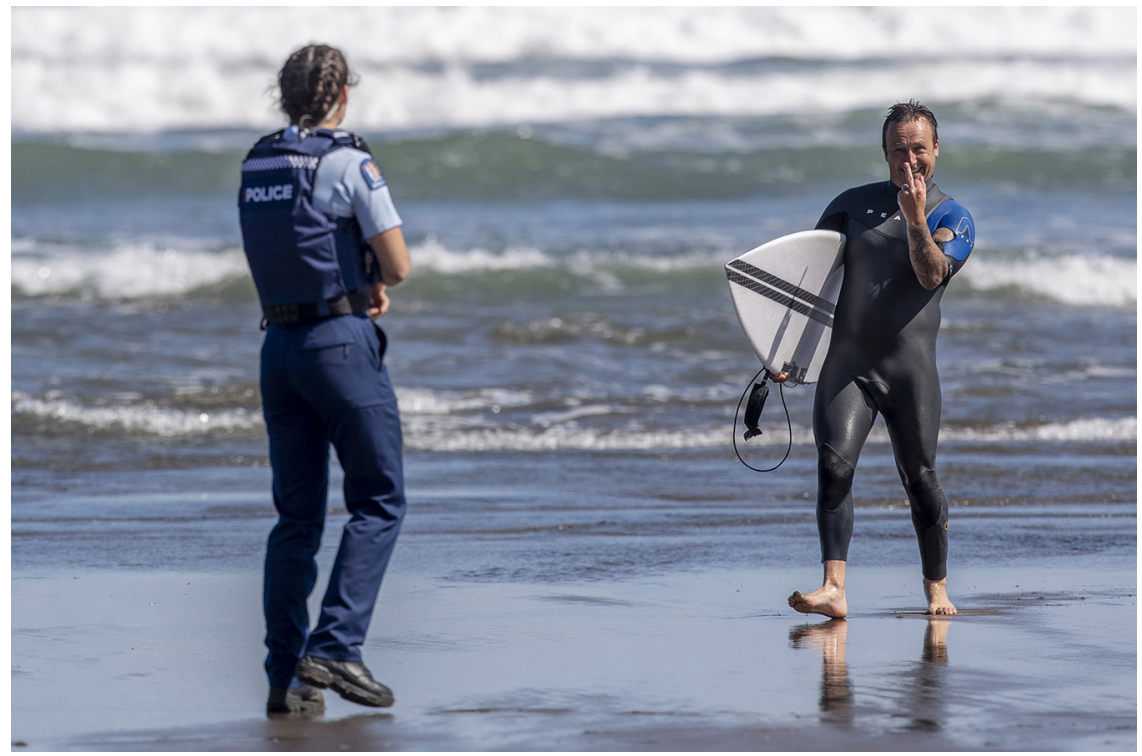

Figure 4. Piha surfer called out of the water by police. Photo by David White.

\section{"RESIDENTS ONLY-STAY IN YOUR NEIGHBOURHOOD"}

In his defense, the surfer claimed media misrepresentation, insisting he'd gestured toward the news photographer, not the officer. He also invoked a new dimension of ethical proximities, referring to his adherence to government regulations to "stay local" (i.e., not travel out of one's neighborhood). "This is my home 
beach," he asserted, "I'm in my community. That photographer has driven all the way out here to stand by the police taking photos" (Sumner 2020).

While the order to "stay local" caused confusion across sub/urban neighborhoods (just how wide is "local"?), in more isolated areas, residential proximities became a marker of safety and solidarity. At Piha and elsewhere, hand-painted signs appeared demanding nonresidents "stay out."

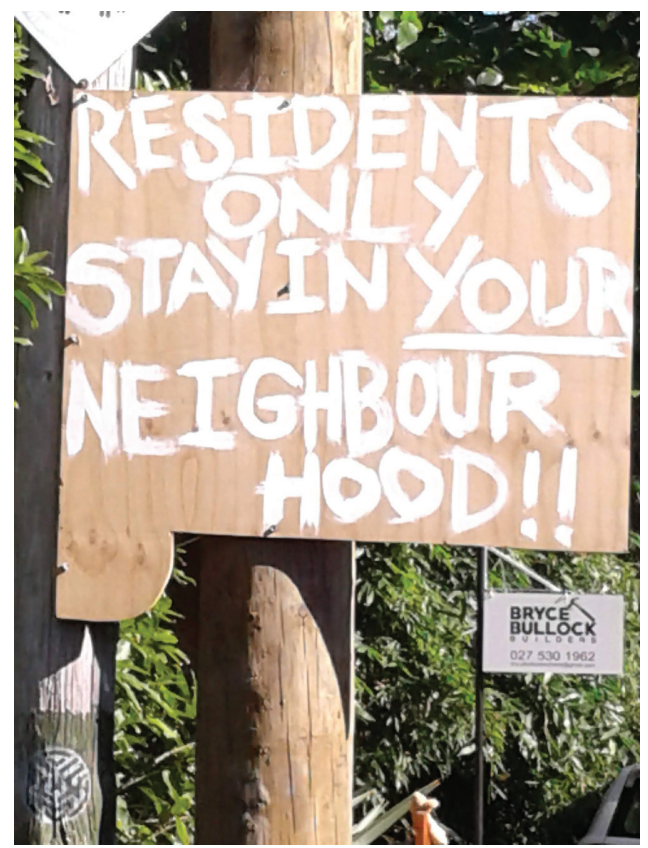

Figure 5. Warning to nonresidents to stay out of Piha, Auckland, June 2020. Photo by Susanna Trnka.

More controversially, barriers--referred to as "roadblocks" or "checkpoints," depending on one's politics--were erected on roads leading to the Far North. In an area whose population is 40 percent Māori (compared to the national average of 16.5 percent) (Stats NZ n.d.), roads were predominantly patrolled by members of local iwi (Māori tribes), enforcing distance between the "us" of local residents, some of whom hold guardianship (kaitiakitanga) of these lands, and potentially contagious outsiders. Practically and symbolically, the barriers suggested state measures would prove ineffective in protecting Māori, evoking, inter alia, previous epidemics' ethnically disproportionate mortality rates (Aoake 2021). They were, moreover, interpreted by critics and supporters as indexing Māoridom's struggle for self-sovereignty (tino rangatiratanga). The right-of-center former politician Don 


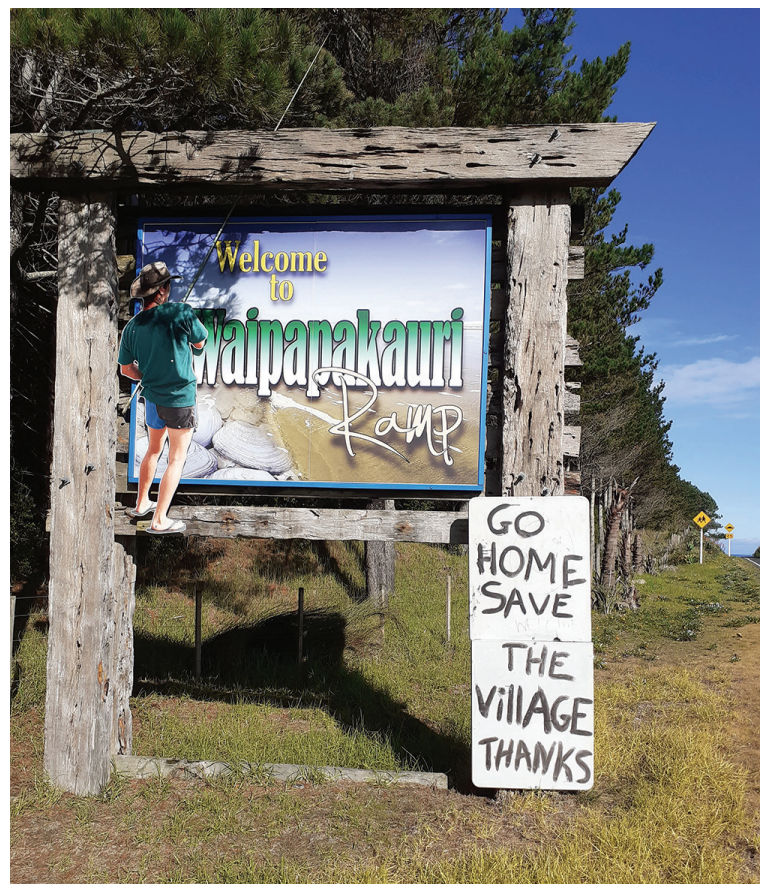

Figure 6. Ninety Mile Beach, Northland, July 2020. Photo by Susanna Trnka.

Brash, for example, denounced checkpoints by declaring, "I think the Government has to stomp on this idea that there are two different legal systems in New Zealand--one for the Māori ancestors [sic] and one for the rest of us" (Sadler 2020). After initially ignoring the situation, the Labour-led government responded to criticism from opposition leaders and from people detained at barriers by announcing that checkpoints must include police representatives, thus simultaneously legitimating and co-opting iwi policing. Checkpoints represent highly visible contestations between the people and the state, confirming Honig's (2009) critique of Giorgio Agamben that assessments of states of emergency in democratic societies must look beyond "the sovereign" to locate the actual bedrock of power in the populace.

While checkpoints challenged government leadership, the group that proved perhaps hardest to integrate into national narratives was expatriate returnees. Part of the appeal of the catchphrase "team of five million" was that New Zealanders were unused to imagining themselves this size; in a curious twist on COVID-19 demographics, Aotearoa's population expanded as expatriates flooded home. The media hailed the reversal of previous "brain drains" as a "brain gain" (Kirkness 2020). Resentment, however, dominated public discourse. 
As weeks of "sacrificed" freedom proved successful (Aotearoa was without community transmission for 102 days straight in 2020), antipathy against returnees who might reintroduce the virus intensified. As L. L. Wynn (2021, this issue) documents for Australia, fears of contagion provoked fault lines in national unity. In Aotearoa, returnees using outdoor exercise areas in government quarantine facilities reported verbal abuse from passersby. Online harassment spiked with news of escapes from quarantine. Formerly "us," citizen-returnees became "effaced," recast as strangers (Simmel 1950; Bauman 1990) and potential COVID-19 carriers, symbolic of irresponsible nations who did not "do it right." Neither citizenship, previous residence, nor ethnic or kinship ties sufficed for inclusion.

\section{CONCLUSION}

It often takes work to constitute and maintain suitable distance and closeness. That this is ethical work is denoted by how we take umbrage at distancing or intimacy that violates our sense of appropriateness. These are "ordinary ethics," born out of situations we navigate by drawing on culturally delineated moral values, legal and bureaucratic prerogatives, and our face-to-face encounters with others (Das 2015; Lambek 2015; Keane 2017). Do I refrain from visiting my friend/ daughter/lover who is in trouble? Do I call the police if I see my neighbor leaving town? Are they us? Or are they too close to us?

The primary reason many people contravened the March 2020 lockdown was to retain closeness suddenly deemed illegitimate. Even though they could email, phone, or Zoom, the ethical summons (Levinas 1969) to respond by being with one another claimed precedence. Lockdown also drove some to demand appropriate practices of farness and fairness from others - what Susan Levine and Lenore Manderson (2021, this issue) refer to as the "ethics of care as distance"-compelled by calls for interpersonal and collective care, respect of the law, and concerns over contagion that strengthened and fractured bonds of commonality.

I have considered four instances in which proximity was mediated: the breaching of regulations; the "dobbing in" of rule-breakers; local boundary maintenance; and the transformation of returnees into strangers. These represent a fraction of how the state of emergency was not just lived through but constituted by the general public: even if the sovereign declares the exception, in democracies sovereignty remains "implicated in and dependent upon popular power" (Honig 2009, 89). With initially minimal police enforcement, Aotearoa's 2020 state of emergency not only required citizen participation but also became the staging 
ground for citizens' (legal/illegal/extralegal) determinations of where and when proximities were extended, revoked, or sustained.

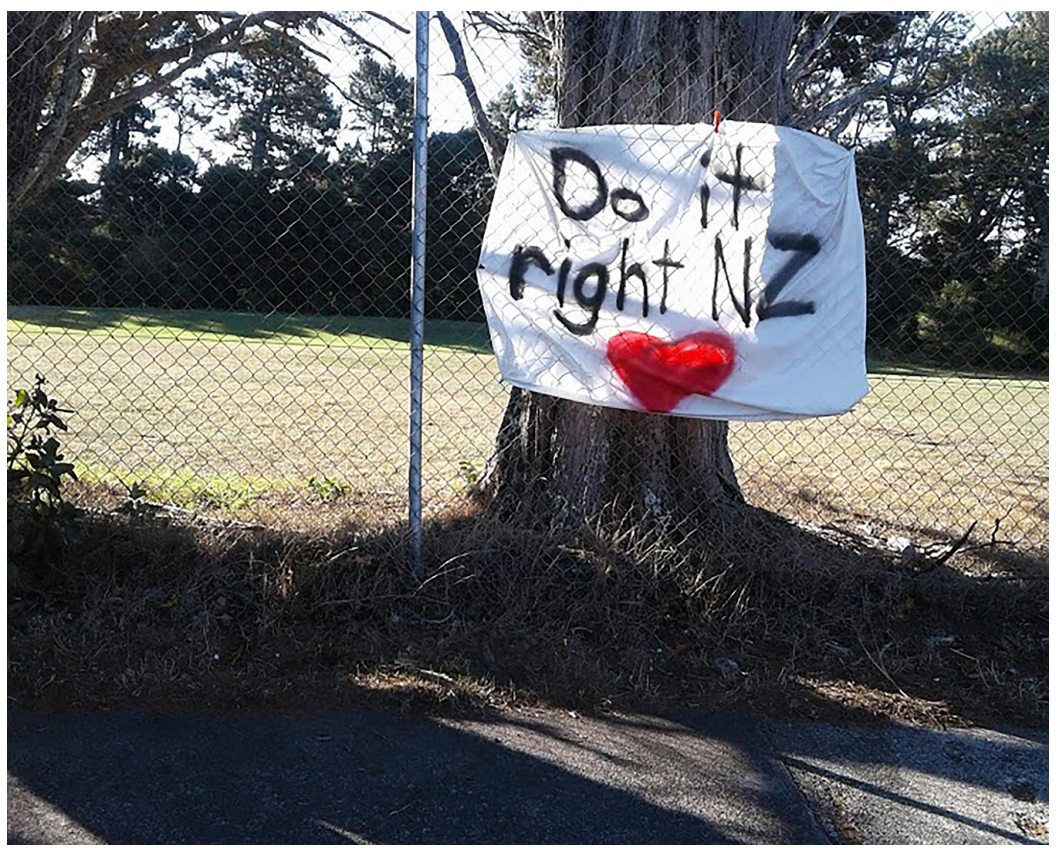

Figure 7. Banner in Green Bay, Auckland, March 2020. Photo by Susanna Trnka.

\begin{abstract}
Citizens do not merely respond to states of emergency; in democratic societies, they help constitute them. This essay analyzes New Zealanders' engagements in ethical reasoning during the country's first COVID-19 lockdown. Specifically, I examine how we can understand a variety of public responses to emergency measures - including breaching regulations, threatening rule-breakers, sealing off neighborhoods, and recasting citizen-returnees as "strangers" - as negotiations of ethical proximities focused on keeping appropriately close that which is thought should be near, and keeping distanced that deemed best held afar. [Aotearoa; COVID-19; ethics; lockdown; New Zealand; proxemics; proximity; social distancing; state of emergency; state-citizen relations]
\end{abstract}

\title{
NOTES
}

Acknowledgments Many thanks to Miriama Aoake, Sharyn Graham Davies, Susan Levine, Lenore Manderson, Brodie Quinn, Carolyn Rouse, Julie Spray, Tom Strong, and Lisa Wynn for comments on this piece. Thank you also to Julie Park for feedback on earlier iterations. I am very grateful for the financial support this research received from the Social Science Research Council's Rapid-Response Grants on COVID-19 and the Social Sciences, and the University of Auckland Faculty of Arts' PBRF fund. 
1. I have chosen this phrasing to distinguish these dynamics from Levinas's "ethics of proximity," as they relate to different (although at times overlapping) concerns.

\section{REFERENCES}

Agamben, Giorgio

2005 State of Exception. Translated by Kevin Attell. Chicago: University of Chicago Press.

2020 "The Invention of an Epidemic." European Journal of Psychoanalysis website, February 26. http://www.journal-psychoanalysis.eu/coronavirus-and-philosophers/.

AMI Insurance

2020 “Kindness Is Everything 60 YouTube May 2020.” YouTube Video, 1:00, May 18.

Aoake, Miriama https://www.youtube.com/watch?v=3iPFi4zDIgI.

2021 "Pandemaurium: Māori Responses to State Management of a Pandemic." Master's thesis, University of Auckland.

Appadurai, Arjun

2020 “The COVID Exception." Social Anthropology / Anthropologie Sociale 28, no. 2: 221-22. https://doi.org/10.1111/1469-8676.12898.

Ardern, Jacinda

2020 "Prime Minister: COVID-19 Alert Level Increased.” Beehive.govt.nz, March 23. https://www.beehive.govt.nz/speech/prime-minister-covid-19-alert-levelincreased.

Bauman, Zygmunt

1990 "Effacing the Face: On the Social Management of Moral Proximity." Theory, Culture and Society 7, no. 1: 5-38. https://doi.org/10.1177/026327690007001001. Chomsky, Noam

2020 "Noam Chomsky: Coronavirus - What Is at Stake?" Interview by Srecko Horvat. DiEM25 TV, YouTube Video, 32:56, March 28. https://www.youtube.com/ watch? $=\mathrm{t}-\mathrm{N} 3 \operatorname{In} 2 \mathrm{rLI} 4$.

Das, Veena

2004 "The Signature of the State: The Paradox of Illegibility." In Anthropology in the Margins: Comparative Ethnographies, edited by Veena Das and Deborah Poole, 22552. Santa Fe, N.Mex.: SAR Press.

2015 "What Does Ordinary Ethics Look Like?" In Four Lectures on Ethics: Anthropological Perspectives, by Michael J. Lambek, Veena Das, Didier Fassin, and Webb Keane, 53-125. Chicago: Hau Books. https://haubooks.org/viewbook/four-lectures-onethics/05_ch02.

Fassin, Didier

2012 Humanitarian Reason: A Moral History of the Present. Translated by Rachel Gomme. Foucault, Michel Berkeley: University of California Press.

2004 Abnormal: Lectures at the Collège de France, 1974-1975. Edited by Valerio Marchetti Honig, Bonnie and Antonella Salomoni. Translated by Graham Burchell. London: Verso.

2009 Emergency Politics: Paradox, Law, Democracy. Princeton, N.J.: Princeton University Press.

Keane, Webb

2017 Ethical Life: Its Natural and Social Histories. Princeton, N.J.: Princeton University Press.

Kirkness, Luke

2020 "The Brain Gain: How Returning Kiwis Will Boost the Economy." NZ Herald, July 6. https://www.nzherald.co.nz/nz/the-brain-gain-how-returning-kiwiswill-boost-the-economy/T72WGFYYF7Z4FGBR35DD6DRZFM/. 
Koselleck, Reinhart

2006 “Crisis." Translated by Michaela W. Richter. Journal of the History of Ideas 67, no. 2: 357-400. https://www.jstor.org/stable/30141882.

Lambek, Michael

2015 “Living As If It Mattered.” In Four Lectures on Ethics: Anthropological Perspectives, by Michael Lambek, Veena Das, Didier Fassin, and Webb Keane, 5-51. Chicago: Hau

Levinas, Emmanuel

Books. https://haubooks.org/viewbook/four-lectures-on-ethics/04_ch01.

1969 Totality and Infinity: An Essay on Exteriority. Translated by Alphonso Lingis. Pittsburgh: Duquesne University Press.

Levine, Susan, and Lenore Manderson

2021 "Proxemics, COVID-19, and the Ethics of Care in South Africa." Cultural

Long, Nicholas Anthropology 36, no. 3: 391-99. https://doi.org/10.14506/ca36.3.06.

2020 "From Social Distancing to Social Containment: Reimagining Sociality for the Coronavirus Pandemic." Medicine Anthropology Theory 7, no. 2: 247-60. https:// doi.org/10.17157/mat.7.2.791.

Long, Nicholas J., Pounamu Jade Aikman, Nayantara Sheoran Appleton, Sharyn Graham

Davies, Antje Deckert, Eleanor Holyrod, Megan Laws, et al.

2020 "Living in Bubbles during the Coronavirus Pandemic: Insights from New Zealand." Rapid Research Report, London School of Economics. http://eprints. lse.ac.uk/104421/.

Owen, Catrin

2020 "Coronavirus: Surfers Continue to Ride the Waves Despite New Lockdown Rules." Stuff, April 5. https://www.stuff.co.nz/national/health/coronavirus/120825454/ coronavirus-surfers-continue-to-ride-the-waves-despite-new-lockdown-rules.

Pink, Sarah, Phil Hubbard, Maggie O’Neill, and Alan Radley

2010 "Walking across Disciplines: From Ethnography to Arts Practice." Visual Studies 25, no. 1: 1-7. https://doi.org/10.1080/14725861003606670.

Roitman, Janet

2013 Anti-Crisis. Durham, N.C.: Duke University Press.

Rouse, Carolyn M.

2021 "Necropolotics versus Biopolitics: Spatialization, White Privilege, and Visibility during a Pandemic.” Cultural Anthropology 36, no. 3: 360-67. https://doi.

Sadler, Rachel org/10.14506/ca36.3.03.

2020 "Coronavirus: Hone Harawira, Don Brash Clash over Use of Community Roadblocks." Newshub, April 1. https://www.newshub.co.nz/home/newzealand/2020/04/coronavirus-hone-harawira-don-brash-clash-over-use-ofcommunity-roadblocks.html.

Silverstone, Roger

2003 “Proper Distance: Towards an Ethics for Cyberspace." In Digital Media Revisited: Theoretical and Conceptual Innovations in Digital Domains, edited by Gunnar Liestøl, Simmel, Georg

Andrew Morrison, and Terje Rasmussen, 469-90. Cambridge, Mass.: MIT Press.

1950 “The Stranger.” Translated by Kurt Wolff. In The Sociology of Georg Simme1, 402-8. New York: Free Press.

Stats NZ

n.d. “2018 Census.” Stats NZ website. Accessed July 27, 2020. https://www.stats.govt. nz/2018-census/.

Strong, Thomas

2021 “The End of Intimacy." Cultural Anthropology 36, no. 3: 381-90. https://doi. org/10.14506/ca36.3.05. 
Sumner, Bonnie

2020 “Surfer Facing Death Threats over Photo." Newsroom, April 8. https://www. Trnka, Susanna newsroom.co.nz/2020/04/08/1119978/surfer-facing-death-threats-over-photo.

2020 "From Lockdown to Rāhui and Teddy Bears in Windows: Initial Responses to Covid-19 in Aotearoa/New Zealand." Anthropology Today 36, no. 5: 11-13. https:// doi.org/10.1111/1467-8322.12603.

Trnka, Susanna, and Sharyn Graham Davies

2021 "Blowing Bubbles: COVID-19, New Zealand's Bubble Metaphor, and the Limits of Households as Sites of Responsibility and Care." In COVID-19: Volume I: Global Pandemic, Societal Responses, Ideological Solutions, edited by J. Michael Ryan, 16783. London: Routledge.

Trnka, Susanna, Nicholas J. Long, Pounamu Jade Aikman, Nayantara Sheoran Appleton, Sharyn Graham Davies, Antje Deckert, Edmond Fehoko, et al.

2021 "Negotiating Risks and Responsibilities during Lockdown: Ethical Reasoning and Affective Experience in Aotearoa New Zealand." Journal of the Royal Society of New Zealand 51, supp. 1: S55-S74. https://doi.org/10.1080/03036758.2020.1865417.

Trnka, Susanna, and Catherine Trundle

2017 "Competing Responsibilities: Reckoning Personal Responsibility, Care for the Other, and the Social Contract in Contemporary Life." In Competing Responsibilities: The Ethics and Politics of Contemporary Life, edited by Susanna Trnka and Catherine Trundle, 1-26. Durham, N.C.: Duke University Press.

Wynn, L. L.

2021 "The Pandemic Imaginerie: Infectious Bodies and Military-Police Theater in Australia." Cultural Anthropology 36, no. 3: 350-59. https://doi.org/10.14506/ ca36.3.02. 